\title{
A Key for Identification of Spiders at Qena Governorate, Upper Egypt
}

\author{
Ahmad H. Obuid-Allah ${ }^{1}$, Amal A. Mahmoud ${ }^{2}$, ElAmier H. M. Hussien ${ }^{2, ~ * ~}$ \\ ${ }^{1}$ Zoology Department, Faculty of Science, Assiut University, Assiut, Egypt \\ ${ }^{2}$ Zoology Department, Faculty of Science, South Valley University, Qena, Egypt \\ Email address: \\ elameer.hussien@sci.svu.edu.eg (E. H. M. Hussien)
}

\section{To cite this article:}

Ahmad H. Obuid-Allah, Amal A. Mahmoud, ElAmier H. M. Hussien. A Key for Identification of Spiders at Qena Governorate, Upper Egypt. American Journal of Life Sciences. Special Issue: New Horizons in Basic and Applied Zoological Research. Vol. 3, No. 6-1, 2015 , pp. 13-23. doi: 10.11648/j.ajls.s.2015030601.13

\begin{abstract}
Spiders are one of the more diverse arthropod taxa, ranking seventh in global diversity, which makes them a fascinating group to study [1]. The correct identification of many spider species is considered problematic due to complex variation in morphology [2]. The Egyptian spider fauna are incompletely known due to scarcity of studies on this group especially in Upper Egypt. So, the present key for identifying terrestrial spiders at Qena Governorate is a part of a comprehensive study conducted at the region to study the ecology and taxonomy of this group. The present key was designed to facilitate identification of terrestrial spiders at Qena Governorate using their morphological characteristics. Samples of spiders were collected during a period of one year (from February, 2012 till January, 2013) from six different sites covering Qena governorate. Qena $\left(15-26^{\circ} \mathrm{N}, 32-50^{\circ} \mathrm{E}\right)$ is located at Upper Egypt about $600 \mathrm{Km}$ south of Cairo and $60 \mathrm{Km}$ north of Luxor and $260 \mathrm{Km}$ west of the Red Sea. Climate of Qena is hot, dry in summer and cold in winter. It rarely rains. Also, it receives a large quantity of solar radiation; especially in summer. Sampling methods of spiders included hand picking, sweep net and pitfall trap. Survey results revealed the occurrence of 14 families that included 23 genera and 23 species. The present key for the collected families and species was designed and illustrated using taxonomic characteristics of each species.
\end{abstract}

Keywords: Systematic Key, Spiders, Qena Governorate, Upper Egypt

\section{Introduction}

Spiders are members of phylum Arthropoda, the large group of animals with jointed legs and hard outer skeleton. They belong more specifically to class Arachnida, which includes animals with four pairs of legs, no antennae or wings, and only two body regions; a cephalothorax which contains (the brain, poison glands and stomach) carapace, sternum, eyes, chelicerae, mouthparts, legs and palps and the abdomen (spinnerets, genitalia, lungs and respiratory tracheae) [3]. Spiders are amongst the most astonishing creatures on Earth. The variety of their form and biodiversity is impressive indeed, with more than 45,000 spider's species belonging to 114 families described so far and many thousands still awaiting discovery and description [4]. Spiders are important in another way; they are a vital component of most terrestrial ecosystems, not least of agricultural systems. They strongly affect the density of insect populations and have been shown to limit insect pests in the agricultural environment [5]. The worldwide spider fauna is still incompletely known. Furthermore, the scientific literature is very scattered, and new species can be found even with the most cursory surveys. Despite these problems there is fair taxonomic literature [6]. As a taxonomic group, spiders are good candidates for bio-indication, because they form a species rich group, inhabiting all kinds of terrestrial ecosystems [7a, b; 8 and 9]. Additionally, each species has its own, well-documented, specific demands concerning humidity, temperature regime and litter and vegetation structure. Bio-indication at the level of the ecological assemblage can address differences in species diversity, species abundance and the occurrence of endangered species [10] and the functional group composition [9].

\section{Materials and Methods}

In the present investigation, samples were collected every 2 weeks during a period of one year (from February, 2012 till January, 2013) from six different sites covering Qena 
governorate (Fig.1). These sites were distributed as follows: $\left(1^{\text {st }}\right.$ site was at Nag hammadi city, $2^{\text {nd }}$ site was at El-Taramsa Village, $3^{\text {rd }}$ site was at the faculty of Engineering, $4^{\text {th }}$ site was at South Valley University, $5^{\text {th }}$ site was at El-Laqita region and the $6^{\text {th }}$ site was at Qus city). Three sampling methods were used in this study which included hand picking, sweep net and pitfall traps. The collected specimens were preserved in $70 \%$ ethanol. Examination was carried out with the aid of binocular stereomicroscope. The identification of specimens was executed on the light of the available taxonomical knowledge, taking in consideration that the group of arachnids is poorly studied in this geographical area. Adult spiders were identified using available literature such as $[11,12]$. Also many keys, papers and catalogues were used for identification which included [13, 14, 15, 1, 16, 17, 18, 6, 19, 20 and 21]. Confirmation of identification was done by Mr. H. K. El-Hennawy the expert in spider's identification of Egypt.

\section{Results}

The total number of specimens of different species of spiders collected through the year of investigation was 1247 specimens forming 23 species belonging to 23 genera that fall in 14 families. All of the collected spiders belong to order: Araneida. The families included: Agelenidae, Araneidae, Gnaphosidae, Linyphiidae, Lycosidae, Miturgidae, Oecobiidae, Oxyopidae, Philodromidae, Pholcidae, Salticidae, Sparassidae, Theridiidae and Thomisidae (Table 1).

Scientific classification of spiders:-

All spiders (Order Araneida or Araneae) belong to class Arachnida, which classified to two suborders, Mesothelae and Opistothelae. The first is a small group found only from Japan to Southeast Asia and called segmented spiders. The Opistothelae are further divided into two infraorders, Mygalomorphae and Araneomorphae and called true spiders. The most obvious distinction between these two is the orientation of the chelicerae, or jaws and the number of book lungs. Mygalomorphs have the chelicerae oriented so that the fangs are parallel to each other and with two pairs of book lungs. The Araneomorphs, which make up the great bulk of spider species worldwide, have the chelicerae oriented so that the fangs oppose each other and with one pair of book lungs [6].

The following taxonomic key was constructed to include only the collected spider families presented by the survey study

1- Cribellum and calamistrum present. Anal tubercle large, two-jointed, with a fringe of long hair (Plate, 1).

- Cribellum and calamistrum wanting. Anal tubercle normal.

2- Eyes in a compact group, eye group hexagonal, arranged in a circle, the posterior row procurved, the anterior row recurved, with the clypeus high. Abdomen pointed behind and legs with very prominent spines (Plate, 2).

- Eyes distributed in rows.

3- Eyes in three rows 4-2-2, anterior median eyes by far the largest, directed forwards, eyes of second row by far the smallest, often minute. Integument usually with scales (Plate, 3 ).

- Eyes in two rows.

4- Legs laterigrade.

- Legs prograde.

5- Big spider, medium to very large, holds their two-clawed legs in a crab-like fashion. The trilobed membrane at the end of the metatarsus is diagnostic (Plate, 4).

- Small spider.

6- Legs I and II much longer and thicker than III and IV. Claw-tufts wanting or formed by simple hairs. Integument with simple hair. Body setae stiff, erect or semi-erect (Plate, 5).

- Legs I (and usually II) little - if at all - longer and thicker than III and IV. Claw-tufts composed of true spatulate hairs. Integument with plumose or squamose hair. Body setae soft, not erect (Plate, 6).

7- Eyes homogenous, diurnal, Eyes in two rows 4-4, Maxillary scoupla well delimited, not extending over external surface (Plate, 7).

- Eyes heterogeneous.

8- Posterior spinnerets considerably shorter than anterior spinnerets, anterior spinnerets widely separated (Plate, 8).

- Anterior spinnerets contiguous or not widely separated.

9- Tarsi long, flexible, pseudo-sub-segmented, lip wide. Eyes either in a compact group or the (6) indirect eyes in 2 triads (Plate, 9).

- Tarsi without pseudo-sub-segments.

10- Fourth tarsus with a comb of ventral serrated bristles (Plate, 10).

- Fourth tarsus without a comb of ventral serrated bristles.

11- Tarsi with trichobothria.

- Tarsi without trichobothria.

12- Eyes in 3 rows, 4-2-2 (Plate, 11).

- Eyes in 2 rows (Plate, 12).

13- Chelicerae often with stridulating file; small spiders (1.5-6 mm) (Plate, 13).

- No cheliceral stridulating file. Bigger spiders (Plate, 14).
Fam. Oecobiidae

2

Fam. Oxyopidae 3

Fam. Salticidae

4

5

7

Fam. Sparassidae

6

Fam. Thomisidae

Fam. Philodromidae

Fam. Eutichuridae 8 Fam. Gnaphosidae 9

Fam. Pholcidae

10

Fam. Theridiidae

11

12

13

Fam. Lycosidae

Fam. Agelenidae

Fam. Linyphiidae

Fam. Araneidae

2- Key to the Recorded Spider Species:

Key for the recorded species of family Araneidae

1. Big abdomen, silver transverse lines and many spots on it ............Argiope trifasciata

2. Broad abdomen, all abdomen with one colour, protrusions on it ... Cyrtophora citricola

3. Long and thin abdomen with one colour.......................... Larinia $\mathrm{sp.}$

Key for the recorded species of family Gnaphosidae 
1-With hard spines on chelicera forward to prosoma, preening comp on the end of III \& IV

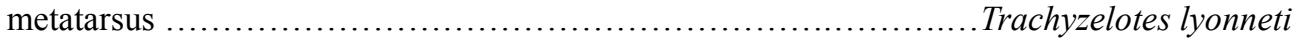

2-No spines and no preening comb Zimiris doriai

Key for the recorded species of family Lycosidae

1. Legs brown banded; white colour on pedipalps

Wadicosa fidelis

2. Legs without brown bands; pedipalps without white colouration. Pardosa sp.

Key for the recorded species of family Oxyopidae

1 - Not green and Legs IV clearly longer than Legs III.......................... Oxyopes sp.

2- Bright Green (living specimen; color fades in alcohol) ......................... Peucetia sp.

Key for the recorded species of family Philodromidae

1- The distance between anterior and median eyes are smaller than the distance between median eyes to each

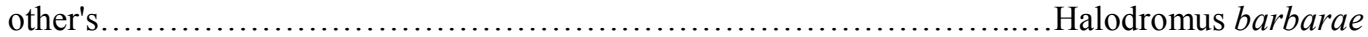

2-The distance between anterior and posterior eyes are equal..................Thanatus albini

Key for the recorded species of family Salticidae

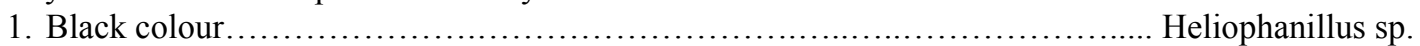

2. Black with longitudinal white colour for male, Brown colour for female......... Plexippus paykulli

3. Brown colour, long setae near posterior median eyes, .................... Thyene imperialis

Key for species of family Theridiidae

1. The anterior median eyes are larger than other eyes......... Paidiscura dromedaria

2. All eyes are equal in size

\section{Discussion}

To the best of the present authors' knowledge and as far as can be ascertained, the present key is the first of its kind at Qena governorate. Survey result of the present study revealed the occurrence of 14 families including 23 genera and 23 species. Some of these families are ground ones, like Lycosidae, Gnaphosidae and Linyphiidae. Others are arboreal as Araniedae, Eutichuridae, Theridiidae, Philodromidae and Thomisidae. Members of families Salticidae, Philodromidae and Araeidae were found to be abundant at all surveyed locations, also they are the most famous families known worldwide for natural control for many agricultural pests. On the other hand, families of Agelenidae, Oxyopidae and Oecobiidae were present at the lowest numbers in the same period of study. Based on the present results and compared with [20 and 22] who studied the same area; one can conclude that all of Cyrtophora citricola, Trachyzelotes lyonneti, Zimiris doriai, Oxyopes sp., Halodromus barbarae and Paidiscura dromedaria are new records at Qena governorate.

\section{List of Abbriviations}

\begin{tabular}{|c|c|}
\hline Anal Tubercle & A small process, dorsal to the spinnerets, carrying the anal opening. \\
\hline Calamistrum (p. calamistra) & A comb of hairs on metatarsus IV of cribellate spiders; used for combing out silk from the cribellum \\
\hline Clypeus (adj. clypeal) & The area between the anterior row of eyes and the anterior edge of the carapace. \\
\hline Colulus & A midline appendage or tubercle arising from just in front of the anterior spinners in some spiders, a nonfunctional cribellum. \\
\hline Cribellate & Pertaining to spiders in which the abdomen has a cribellum. \\
\hline Cribellum & A spinning organ in the form of a transverse plate, just in front of the spinnerets in some cribellate spiders. \\
\hline Cheliceral teeth & Large and/or tiny tooth like projections on the cheliceral furrow margins. \\
\hline Claw & A strong, curved, sharp-pointed process (often toothed) on the distal extremity of a leg or female's palp. \\
\hline Claw tuft & A bunch of hairs at the tip of the leg tarsus in those spiders with two claws. \\
\hline Comb & It is a series of serrated spines which they use to comb out the silk from the spinnerets. \\
\hline Eye tubercle & Mygalomorphs, eye turret, eyes grouped together on a turret \\
\hline Laterigrade & $\begin{array}{l}\text { Denotes the orientation of the legs of some spiders, which are rotated on their bases so that the prolateral surface is uppermost; } \\
\text { also describes the mode of locomotion of such spiders, mainly in the family Thomisidae. }\end{array}$ \\
\hline Metatarsus & The sixth segment of the leg, counting from the body end, not found in the palps. \\
\hline Procurved & Curved as an arc having its ends anterior to its centre. \\
\hline Prograde & $\begin{array}{l}\text { Denotes the normal or nonlaterigrade orientation of the legs in spiders with limbs not rotated on their bases; also used to } \\
\text { describe the mode of locomotion of such spiders. }\end{array}$ \\
\hline Recurved & Curved as an arc having its ends posterior to its centre. \\
\hline Scopula & A brush of hairs on the ventral aspect of the tarsus and metatarsus in some spiders. \\
\hline Spinnerets & Paired appendages at the posterior end of the abdomen, through its spigots silk are extruded. \\
\hline Stridulating organ & $\begin{array}{l}\text { An area with numerous sclerotized, parallel striate which are rubbed by hairs or a tooth on an opposing structure thus creating } \\
\text { sound. Can be located on the palps, legs, chelicerae, abdomen or the carapace. }\end{array}$ \\
\hline Tarsal claw & Sharp curved structure at the tip of the tarsus, typically on the palp and 2 or 3 on the legs. \\
\hline Trichobothrium & A long, fine hair rising almost vertically from a hemispherical socket on the legs, which detect air vibration and currents. \\
\hline
\end{tabular}


Table 1. Shows the identified families and species at the investigated sites.

\begin{tabular}{|c|c|c|c|c|c|}
\hline No. & Family & Species & No. & Family & Species \\
\hline $\begin{array}{l}1 \\
2\end{array}$ & \multirow{3}{*}{ Araneidae [25] } & $\begin{array}{l}\text { Benoitia lepida }[24] \\
\text { Argiope trifasciata }[25]\end{array}$ & 13 & Oxyopidae [37] & Peucetia sp. \\
\hline 3 & & Cyrtophora citricola [26] & 14 & \multirow{2}{*}{ Philodromidae [37] } & Halodromus barbarae [38] \\
\hline 4 & & Larinia sp. & 15 & & Thanatus albini $[30]$ \\
\hline 5 & Eutichuridae [27] & Cheiracanthium siwi [28] & 16 & Pholcidae [39] & Artema Atlanta [40] \\
\hline 6 & \multirow{2}{*}{ Gnaphosidae [29] } & Trachyzelotes lyonneti [30] & 17 & \multirow[b]{2}{*}{ Salticidae $[41]$} & Heliophanillus sp. \\
\hline 7 & & Zimiris doriai $[31]$ & 18 & & Plexippus paykulli [30] \\
\hline 9 & \multirow{2}{*}{ Lycosidae [34] } & Pardosa sp. & 20 & Sparassidae [43] & Eusparassus walckenaeri [30] \\
\hline 10 & & Wadicosa fidelis [35] & 21 & \multirow{2}{*}{ Theridiidae [34] } & Paidiscura dromedaria [44] \\
\hline 11 & Oecobiidae [36] & Oecobius putus [24] & 22 & & Theridion sp. \\
\hline 12 & Oxyopidae [37] & Oxyopes sp. & 23 & Thomisidae [34] & Thomisus spinifer [35] \\
\hline
\end{tabular}

Total: 14 Fmailies

: 23 genera

$: 23$ species

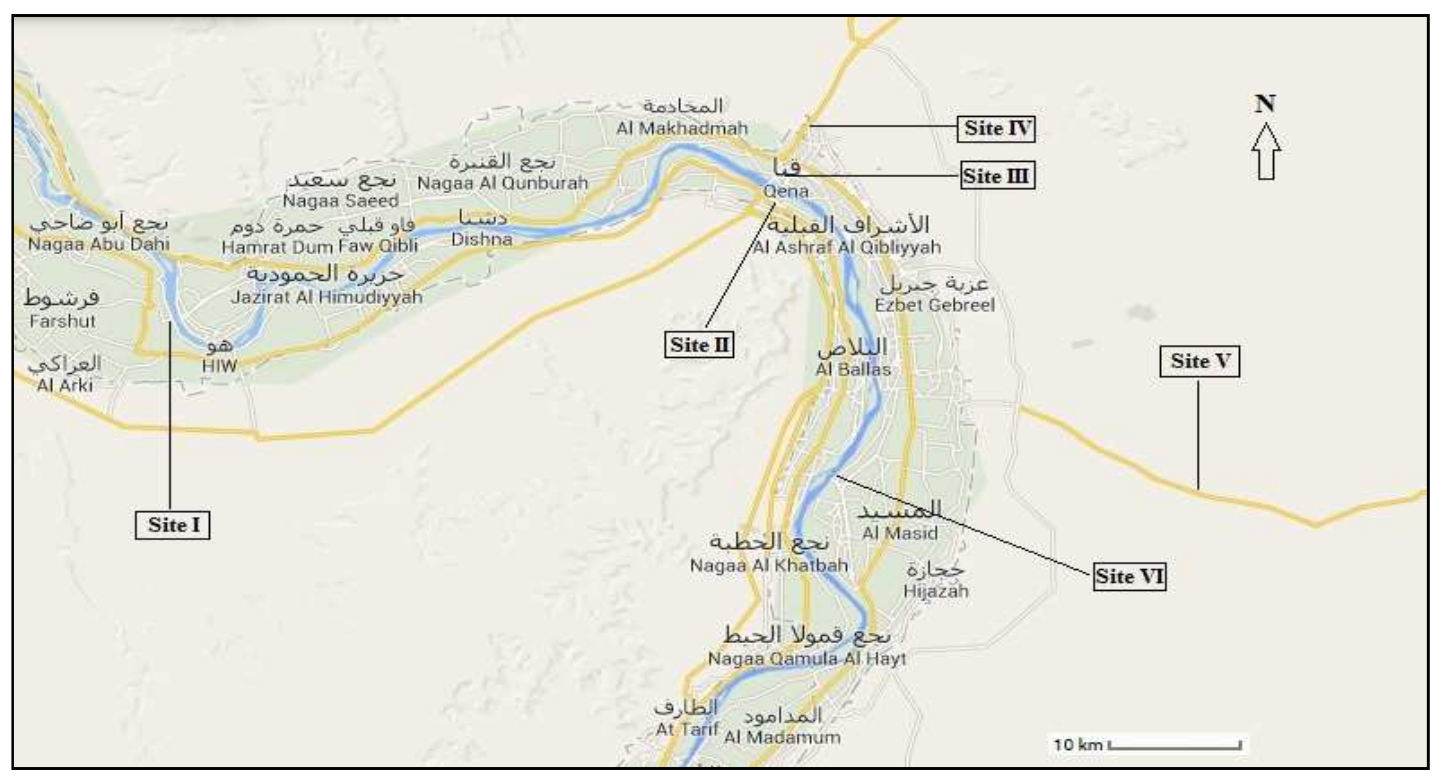

Figure 1. A map of Qena governorate showing the sites of collections.
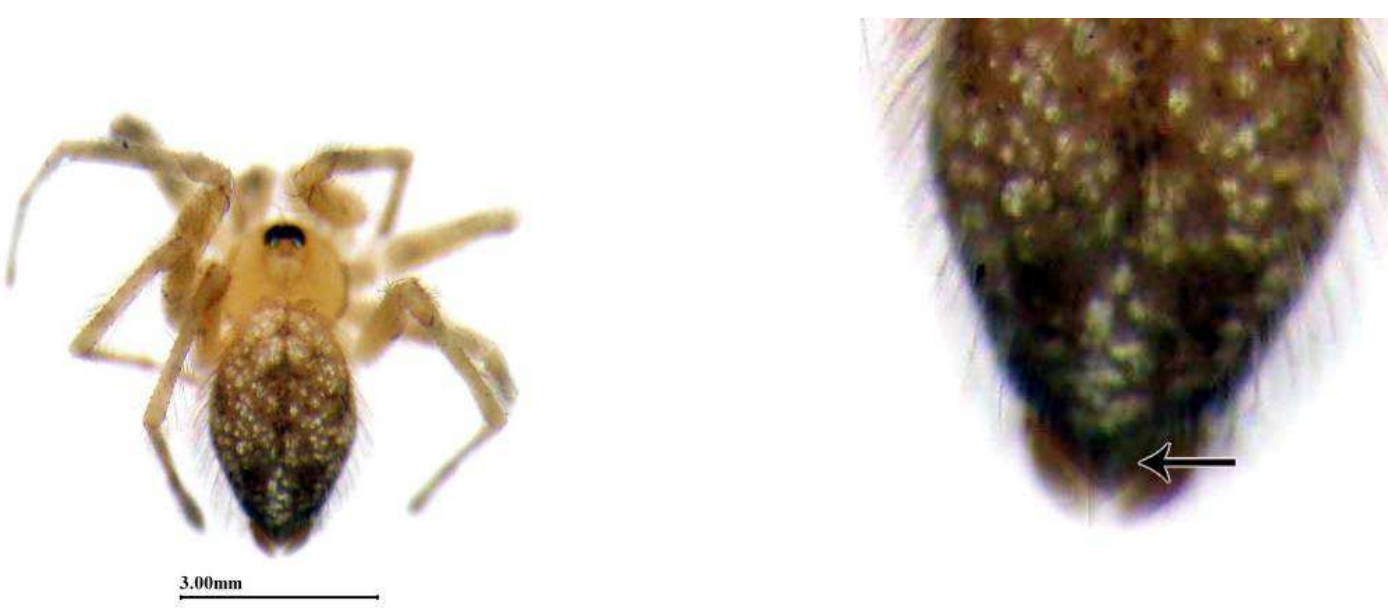

$2 \mathrm{~mm}$.

Plate (1). Showing, A: Dorsal view of Oecobius putus B: Anal tubercle is prominent and has a fringe of long hairs. 


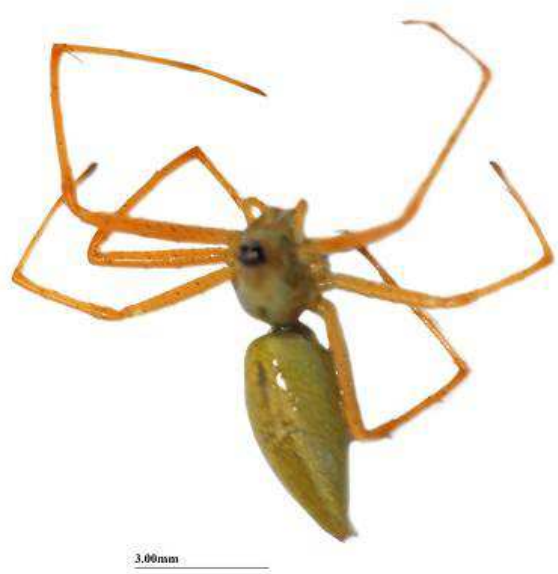

B

Plate (2). Showing, A: Dorsal view of Peucetia sp. B: Carapace with eyes distribution forming hexagonal shape.

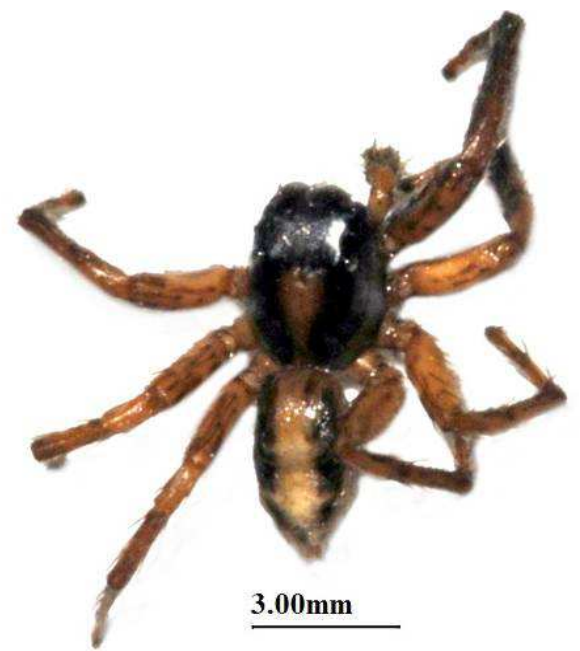

$\mathrm{C}$

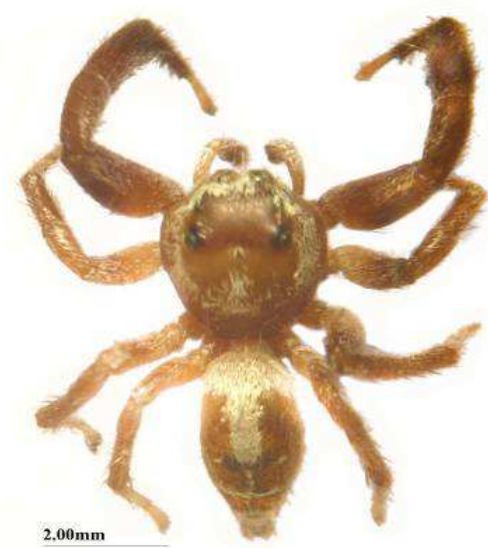

B

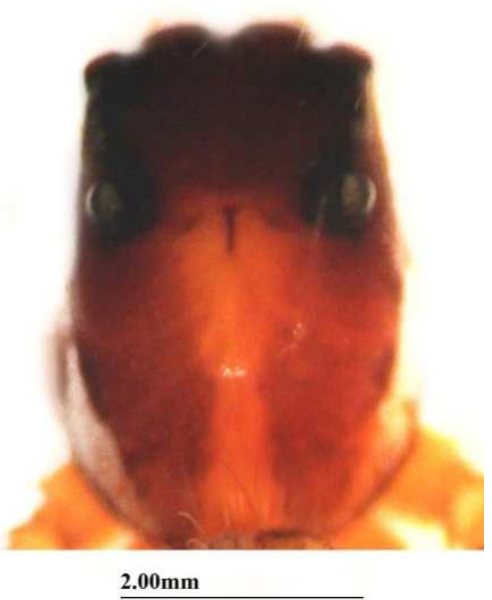

$\mathrm{D}$

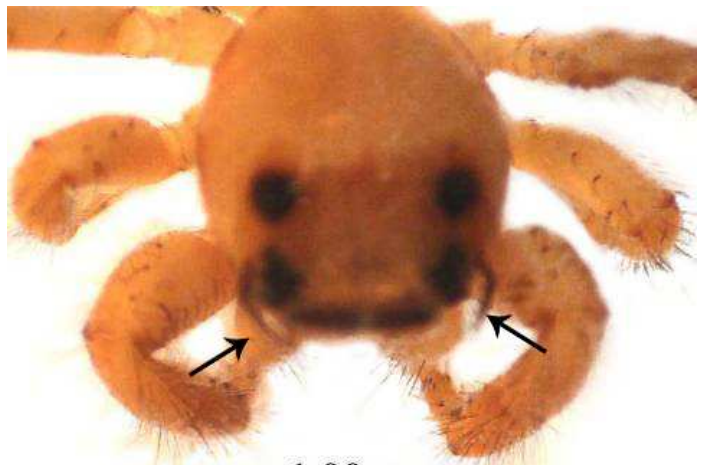

$1.00 \mathrm{~mm}$

Plate (3). Showing A: Dorsal view of Plexippus paykulli B: Carapace with eyes distribution showing anterior eye row barely or not at all wider than posterior eye row. C: Dorsal view of Thyene imperialis. D: Carapace with eyes distribution showing horns-tufts of long black setae, one on each lateral side of the eye field. 

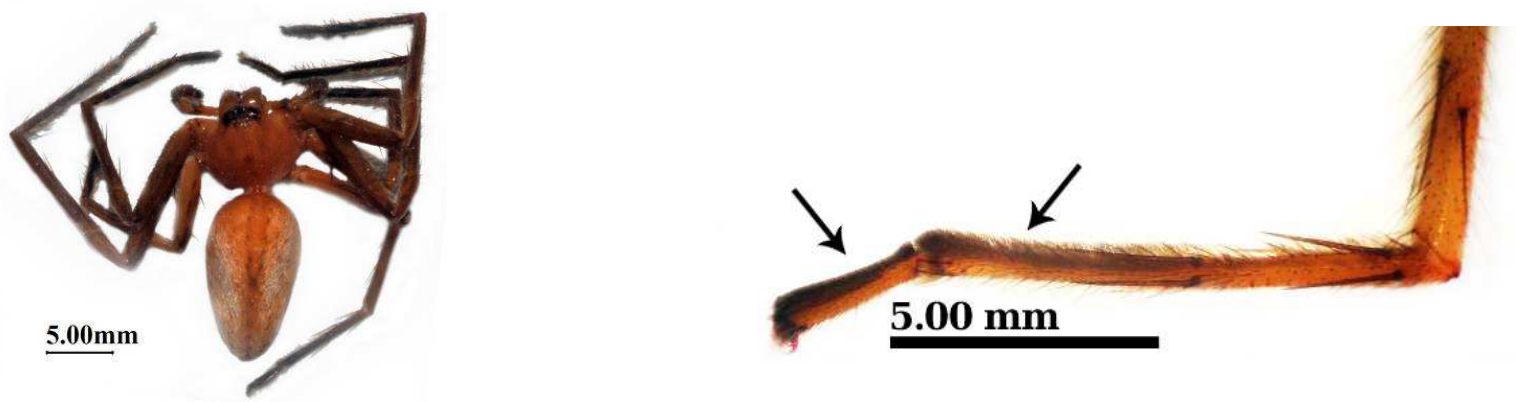

Plate (4). Showing, A: Dorsal view of Eusparassus walckenaeri. B: Tarsi and metatarsi with large scopulae (adhesive hairs) on tarsus and metatarsus.

A

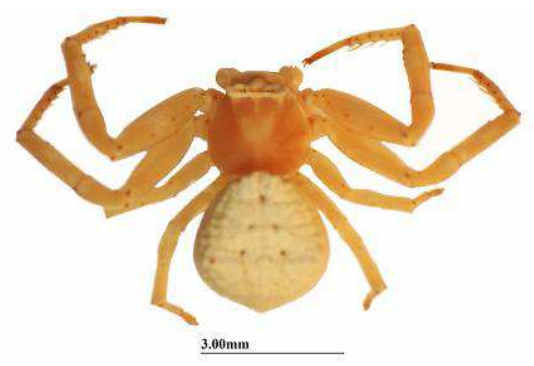

B

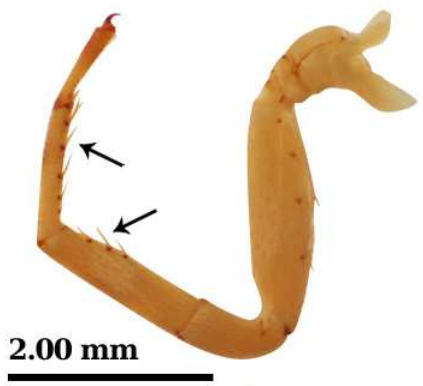

Plate (5). Showing, A: Dorsal view of Thomisus spinifer B: Tibia and metatarsi of legs I provided with strong macro-setae ventrally.

A

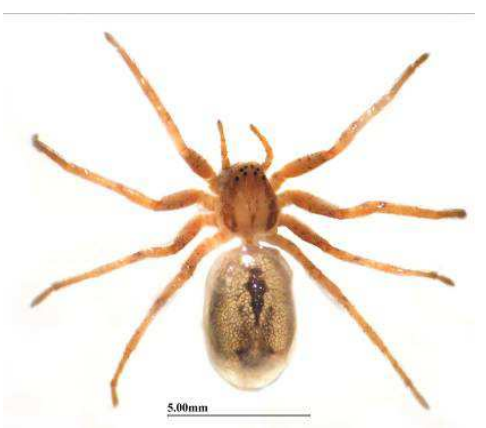

$\mathrm{C}$

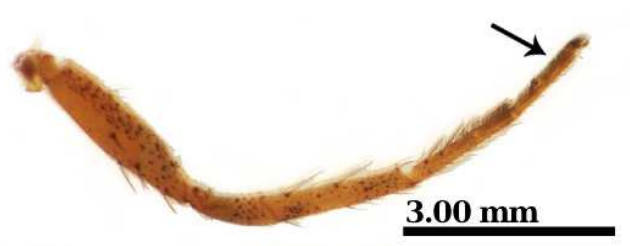

B

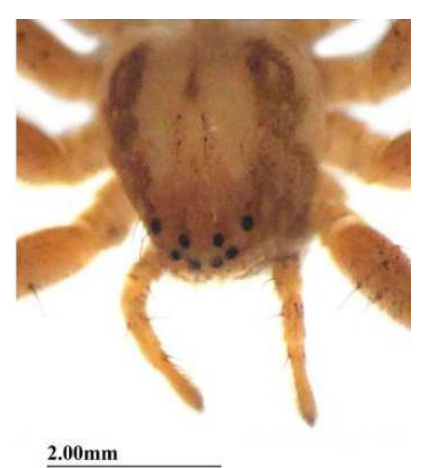

$\mathrm{D}$

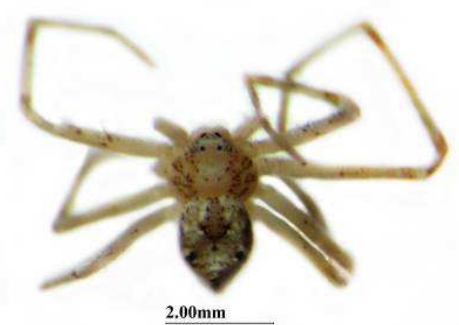

Plate (6). Showing, A: Dorsal view of Thanatus albini B: Eyes distribution showing posterior lateral eyes not elevated on tubercles C: Tarsi I and II with scapulae (thick dense setae). D: Dorsal view and habitus of Halodromus barbarae showing legs shape and length (legs I and II held to the side of the body like a crab rather than held in front of the spider, leg II much longer than legs I, III, and IV). 

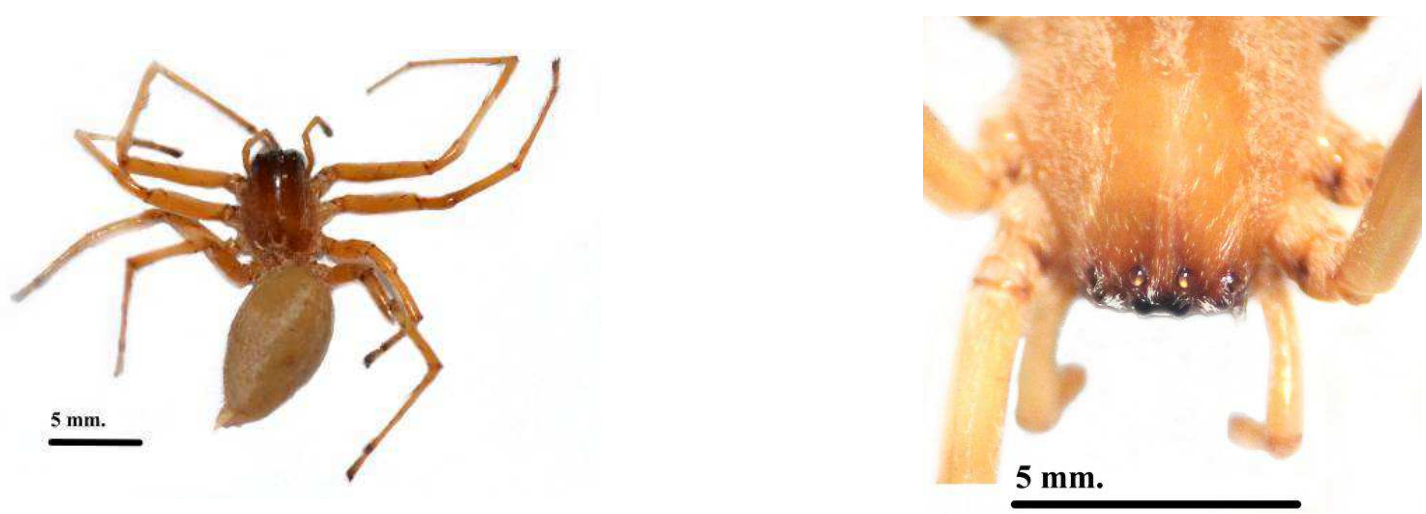

$\mathrm{C}$

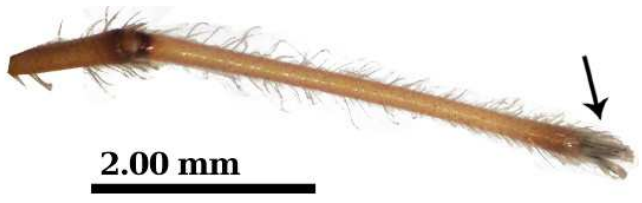

Plate (7). Showing, A: Dorsal view and habitus of Cheirachanthium siwi showing legs long, leg I considerably longer than leg II). B: Carapace with eyes, distribution (homogenous and in two rows 4-4). C: Dense claw tufts and moderately dense scapulae.

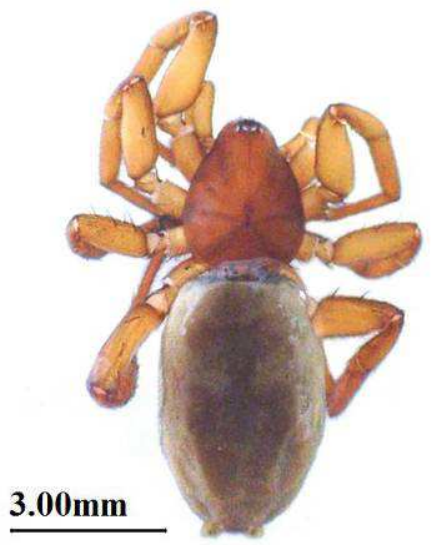

B

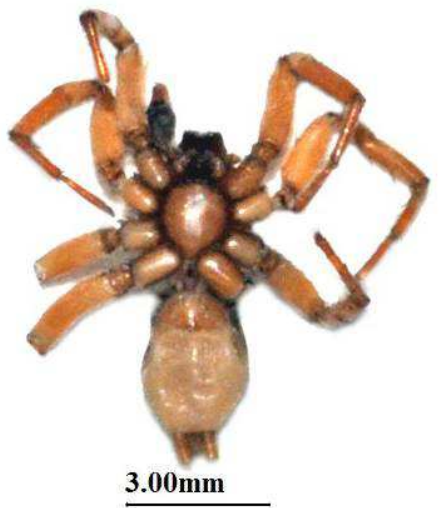

Plate (8). Showing, A: Dorsal view of Trachyzelotes lyonneti B: Ventral view of cylindrical separated anterior spinnerets.

A

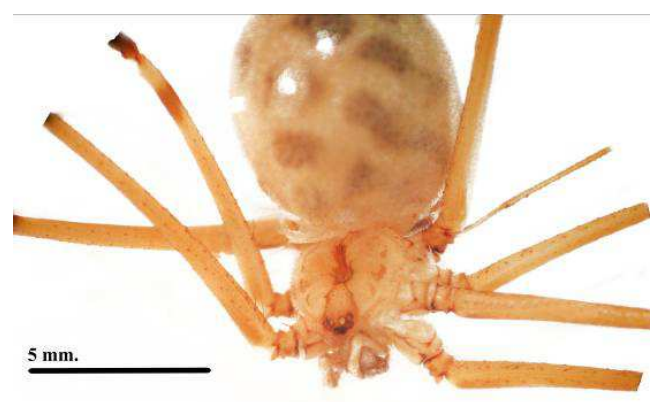

B

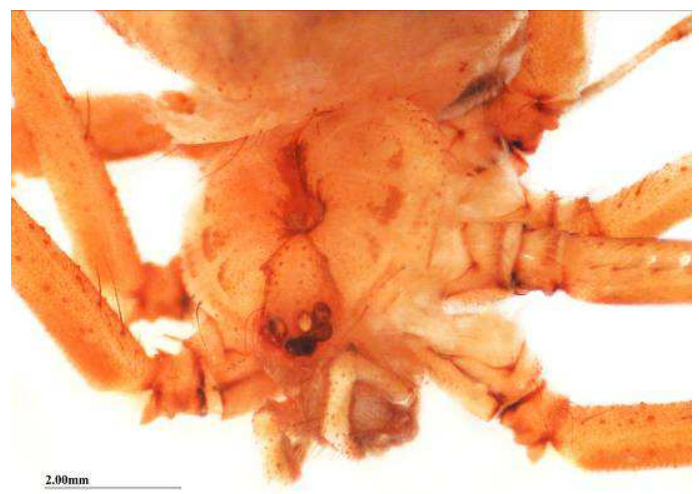


C

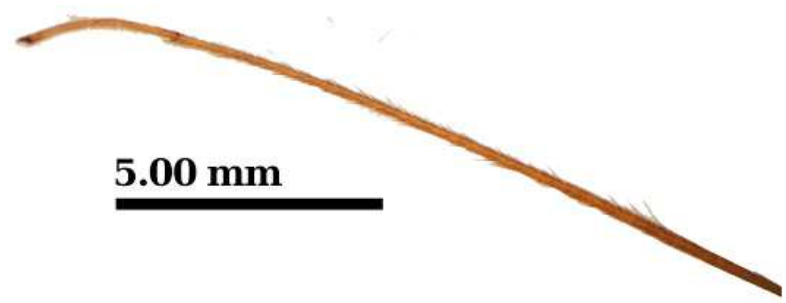

Plate (9). Showing, A: Dorsal view of Artema atlanta B: Carapace with eyes distribution C: Tarsi long and flexible, appearing to have many little segments.

A

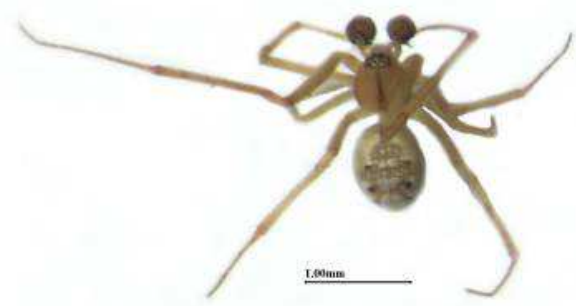

B

C

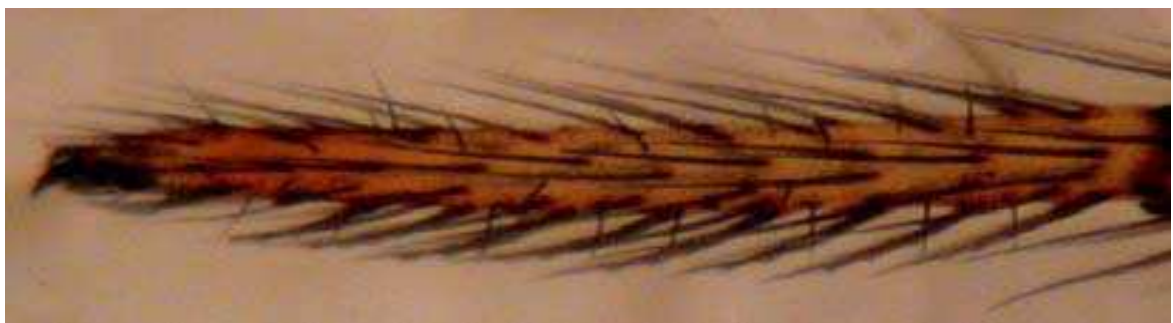

http://www.pholcidae.de/spider_key/Theridiidae.htm

Plate (10). Showing, A: Dorsal view of Paidiscura dromedaria B: Dorsal view of Theridion sp. C: Serrated comb on $4^{\text {th }}$ tarsus.

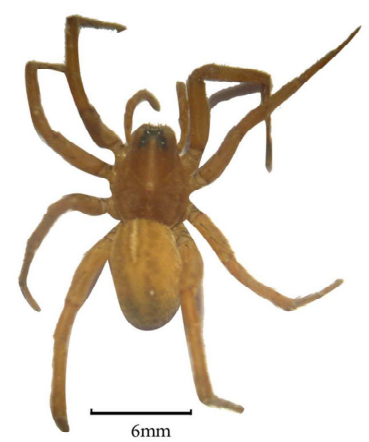

B

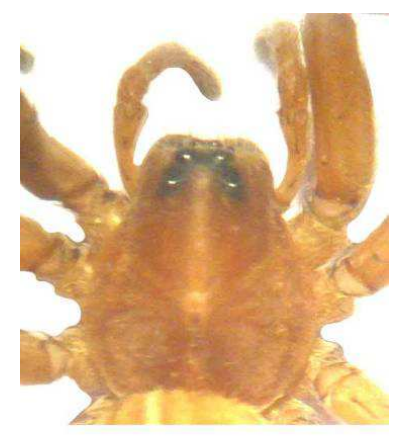

$3.00 \mathrm{~mm}$

Plate (11). Showing A: Dorsal view Pardosa sp. B: Eyes in three rows, posterior eyes larger than anterior eyes. 

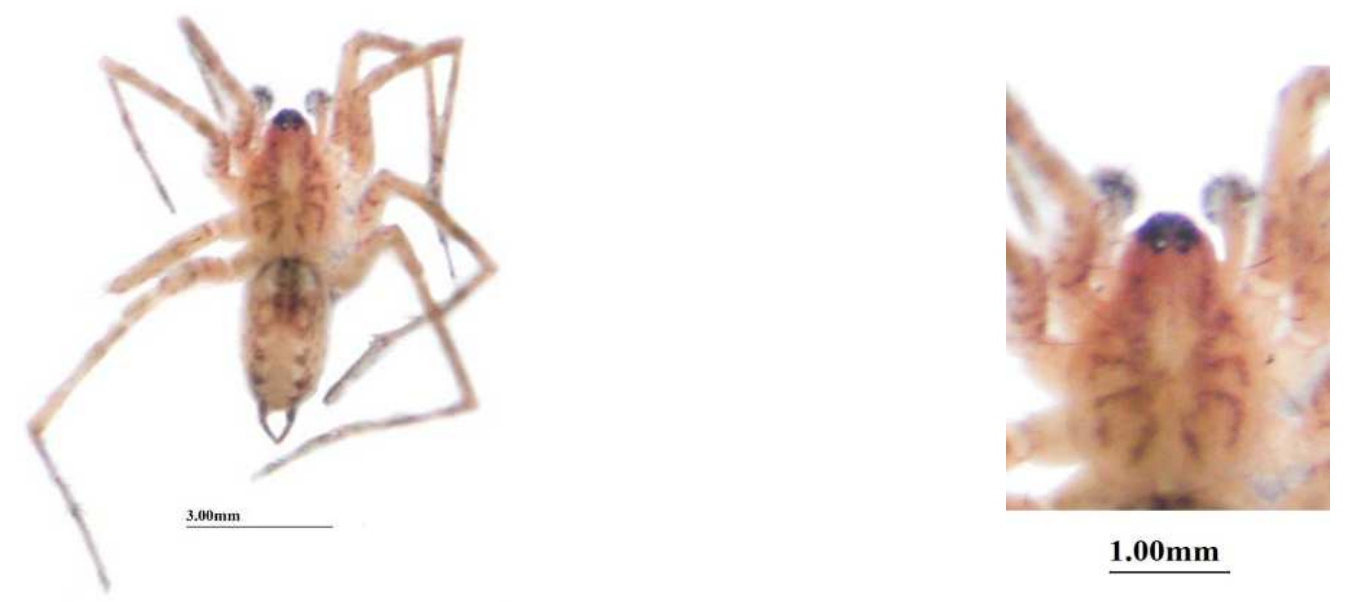

Plate (12). Showing, A: Dorsal view of Benoitia lepida B: Carapace with eye distribution.

A

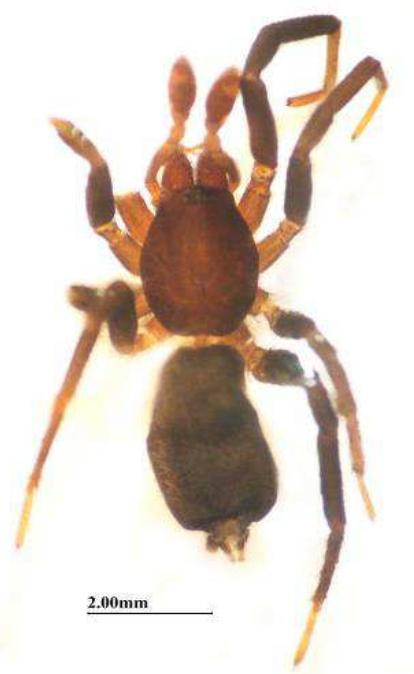

B
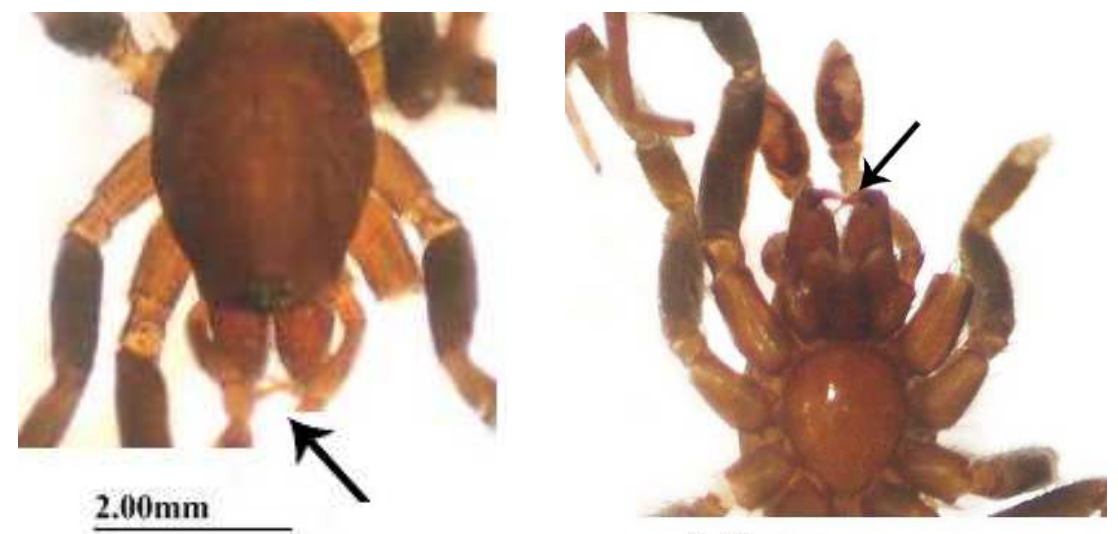

\section{$2.00 \mathrm{~mm}$}

Plate (13). Showing A: Dorsal view of Erigone dentipalpis, B: Dorsal, ventral and frontal view of chelicerae with lateral stridulating ridges; lateral condyle of the chelicerae lacking (sheet-web spiders).

A

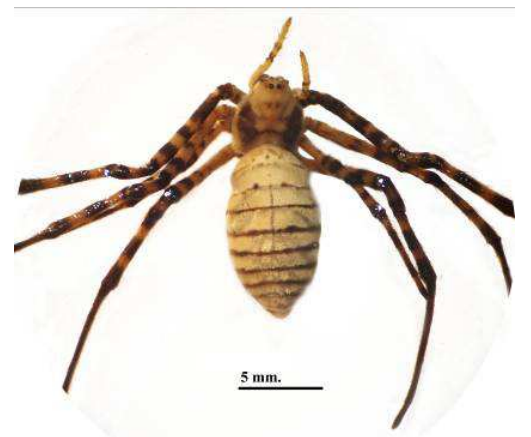

B

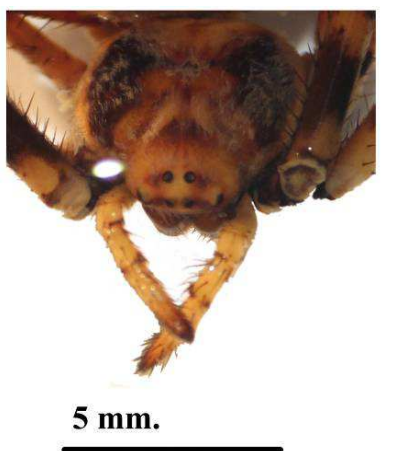

Plate (14). Showing, A: Dorsal view of Argiope trifasciata B: Ventral view C: Carapace with eye distribution. 


\section{Acknowledgement}

We wish to express our sincere and gratitude thanks to $\mathrm{Mr}$. H. K. El- Hennawy, the arachnology expert of Egypt, Cairo, for his helps in confirming the identification of different taxa collected and for the references he provided.

\section{References}

[1] Coddington, J. A. and Levi, H. (1991): Systematics and evolution of spiders (Araneae). Annu. Rev. Ecol. System, 22: 565-592.

[2] Barrett, R. D. H. and Hebert, P. D. N. (2005): Identifying spiders through DNA barcodes. Can J. Zool. 83:481-491.

[3] Levi, H. W. and Levi, L. R. (1990): Spiders and Their Kin. A golden Guide. Golden Press, New York, 160pp.

[4] World Spider Catalog (2015): World Spider Catalog. Natural History Museum Bern, online at http://wsc.nmbe.ch, version 16, accessed on $\{$ May 10, 2015\}.

[5] Wise, D. H. (1993): Spiders in Ecological Webs. Cambridge University Press, Cambridge, UK., 342 pp.

[6] Sewlal, J. N. and Cutler, B. (2003): Annotated list of spider families of Trinidad and Tobago (Araneida). Living World, J. Trinidad and Tobago Field Naturalists' Club, 9-13.

[7] Maelfait, J.P. and Baert, L. (1988a): Les araignées sont-elles de bons indicateurs écologiques? C.R. Xème Coll. europ. Arachnol., Bulletin de la Société scientifique de Bretagne 59, H.S. 1: 155-160.

[8] Maelfait, J.P. and Baert, L. (1988b): L'usage pratique des araignées en tant qu'indicateurs écologiques. C.R. Xlème Coll. europ. Arachnol. TUB Dokurnentation Kongresse $u$ nd Tagungen, Berlin 38: 110-117.

[9] Maelfait, J. P. (1996): Spiders as bioindicators. In: VAN STRAALEN, N.M. \& KRIVOLUTSKY, D.M. [eds.]. Bioindicator Systems for Soil Pollution. Kluwer Academic Publishers, Dordrecht: 165-178.

[10] Marc, P.; Canard, A. and Ysnel, F. (1999): Spiders (Araneae) useful for pest limitation and bioindication. Agric., Ecosyst. Environ. 74:229-273.

[11] Maelfait, J. P.; Baert, L.; Janssen, M. and Weireldt, A. M. (1998): A Red List for the spiders of Flanders. Bulletin de l'Institut Royal des Sciences Naturelles de Belgique, Entomologie, 68: 131-142.

[12] Tikader, B. K. (1987): Handbook of Indian Spiders. Calcutta, Zoological Survey of India, $251 \mathrm{p}$.

[13] Barrion, A. T. and Litsinger, J. A. (1995): Riceland spiders of South and Southeast Asia. CAB International, Wallingford, England, $736 \mathrm{p}$.

[14] Petrunkevitch, A. (1939): Catalogue of American Spiders. Vol. 1. Trans. Connect. Acad. Sei., 33: 133-338.

[15] Levi, H. W. and Levi, L. R. (1968): A Guide to Spiders and Their Kin., Golden Press. New York: 160 pp.
[16] Kaston, B. J. (1978): How to know the spiders. $3^{\text {rd }}$ Ed, W.C. Brown Co., Dubuque, Iowa, U.S.A., 272 pp.

[17] Roth, V. D. (1993): Spider genera of North America. Private Publication. Portal, AZ., 201 p.

[18] Dippenaar-Schoeman, A. S. (1977): The biology of Pardosa crassipalpis Purcell (Araneae: Lycosidae), Journal of the Entomological Society of Southern Africa, 40: 225-236.

[19] Levi, H. W.; Levi, L. R.; Zim, H. S. and Strekalovsky, N. (2002): Spiders and Their Kin, Golden Books Publishing Company, New York.

[20] Ubick, D.; Paquin, P.; Cushing, P. E. and Roth, V. (eds). (2005): Spiders of North America: an identification manual. American Arachnological Society, www.americanarachnology.org.

[21] EI-Hennawy, K. H. (2006): A list of Egyptian spiders (revised in 2006). Serket (2006) vol. 10 (2): 65-76.

[22] Jocqué, R. and Dippenaar-Schoeman, A. S. (2006): Spiders families of the world. Belgium, Peteers nv, Royal Museum for Central Africa, 336p.

[23] Hussien, E. H. M. (2011): Taxonomical and Ecological Studies on terrestrial spiders (Arachnida) in Qena City, M.Sc. thesis, Zoology Department faculty of science, South Valley University, $217 \mathrm{pp}$.

[24] Koch, C. L. (1837): Uebersicht des Arachnidensystems 1. C. H. Zeh'sche Buchhandlung, Nürnberg, 39 pp.

[25] Cambridge, O. P. (1876): Catalogue of a collection of spiders made in Egypt, with descriptions of new species and characters of a new genus. Proc. zool. Soc. Lond. 1876: 541-630. p.558.

[26] Simon, E. (1895): Histoire naturelle des Araignées. Vol. 1. Roret, Paris, 1084 pp.

[27] Forskål, P. (1775): Descriptiones Animalium, Avium, Amphibiorum, Piscium, Insectorum, Vermium; quae in itinere orientali. Ed. Carsten Niebuhr. Hauniae, 1775. 164 pp.

[28] Lehtinen, P. T. (1967): Classification of the cribellate spiders and some allied families with notes on the evolution of the suborder Araneomorpha. Annales Zoologici Fennici 4, 468 pp.

[29] EI-Hennawy, K. H. (2001): Catalogue and Bibliography of Genus Cheiracanthium C. L. Koch, 1839 (Arachnida: Araneida: Miturgidae). Serket, 7(4): 114-155.

[30] Pocock, R. I. (1898): The Arachnida from the province of Natal, South Africa, contained in the collection of the British Museum. Ann. Mag. nat. Hist., 2 (7): 197-226.

[31] Audouin, V. (1825): Explication sommaire des planches d'Arachnides de l'Égypte et de la Syrie, publiée par Jules-César Savigny. In: Description de l'Égypte ou Recueil des observations etdes recherches qui ont été faites en Égypte pendant l'Expédition de l'armée française. Histoire Naturelle. Tome Premier 1809. Paris. 4e partie, pp. 99-186. Atlas: pls. 1-9 (Arachnides).

[32] Simon, E. (1882): Viaggio ad Assab nel Mar Rosso,dei signori G.Doria ed O.Beccari con il R.Avviso "Exploratore" dal 16 Novembre 1879 al 26 Febbraio 1880. II. Etude sur les Arachnides de l'Yemen Méridional. Ann.Mus.Civ.St.Nat.Genova, 18: 207-260, pl.8. 
[33] Blackwall, J. (1859): Descriptions of newly discovered spiders captured by James Yate Johnson Esq., in the island of Madeira. Ann. Mag. Nat. Hist., (Ser. 3), 4:255-267.

[34] Wider, K. F. (1834): Beschreibung der Arachniden. In: REUSS A. (Hrsg.): Zoologische Miscellen. - Abh. Mus. Senckenberg, 1: $195-281$.

[35] Sundevall, C. J. (1833): Conspectus Arachnidum. Londini Gothorum, pp. 1-39.

[36] Cambridge, O. P. (1872a): General list of the spiders of Palestine and Syria, with descriptions of numerous new species, and characters of two new genera. Proc. zool. Soc. Lond. 1871: 212-354.

[37] Cambridge, O. P. (1872b): Descriptions of twenty-four new species of Erigone. Proc. zool. Soc. Lond. 1872: 747-769.

[38] Blackwall, J. (1862): Descriptions of newly-discovered spiders from the Island of Madeira. Ann. Mag. Nat. Hist., (Ser. 3), 9:370-382.

[39] Thorell, T. (1870): On European Spiders. Nova Acta Regicae Societatis Scientiarum Uppsaliensis, 7: 109-242.
[40] Muster, C. (2009): The Ebo-like running crab spiders in the Old World (Araneae, Philodromidae). ZooKeys, 16: 47-73.

[41] Koch, C. L. (1851): Übersicht des Arachnidensystems 5. C. H. Zeh'sche Buchhandlung, Nürnberg, 104 pp.

[42] Walckenaer, C. A. (1837): Histoire Naturelle des Insectes Aptères. (Paris) 1: 1-682 pl. 1-15.

[43] Blackwall, J. (1841): On the number and structure of the mammillae employed by spiders in the process of spinning. Trans. Linn. Soc. London, 18:219-224.

[44] Rossi, F. W. (1846): Neue Arten von Arachniden des k.k. Museums, beschrieben und mit Bemerkungen uber verwandte Formen begleitet. Naturw. Abh. Wien, 1: 11-19.

[45] Bertkau, P. (1872): Ueberdie Respirationsorgane der Araneen.lnaugural-Dissertation zur Erlangung der Doctorwllrde der philosophischen Fakultat der Rheinischen FriedrichWilhelms-Universitat zu Bonn. - Arch. Naturg., 38 (2): 208-233.

[46] Simon, E. (1880): Descriptions de trois nouvelles espèces d'Arachnides d'Egypte, reçues de M. A. Letourneux. Ann. Soc. ent. Fr., (5)10.Bull: 98-99. 